\title{
Reformas Políticas E O Regime Da Prefeitura Em Cabo Verde Da Primeira Metade Do Séc. Xix (1832-1834).
}

\author{
Eduardo Adilson Camilo Pereira ${ }^{1}$
}

\section{RESUMO}

Este artigo procura compreender as reformas políticas e a nova reconfiguração administrativa, com a introdução do regime da prefeitura em Cabo Verde, na primeira metade do séc. XIX (1832-1834). Além disso, procura analisar essas reformas em decorrência das novas exigências da elite política local, como forma de manutenção do seu poderio tanto político quanto econômico.

Plavras-chave: Cabo Verde; Regimes políticos; Reformas administrativas; \begin{abstract}
This article seeks to understand political reforms and new administrative reconfiguration, with the introduction of the system of city government in Cape Verde, in the first half of the 19th century (1832-1834). Furthermore, analyzes these reforms as a result of growing demand for local political elite as a way of maintaining their power both political and economic.
\end{abstract}

Keywords: Cape Verde; Political Regimes; administrative reforms;

1 Professor Doutor na Universidade de Cabo Verde e no Instituto de Ciências Jurídicas e Sociais, ambas na cidade da Praia. É também membro da Cátedra Amílcar Cabral. 


\section{MAPA 1 - DE CABO VERDE - DETALHES}

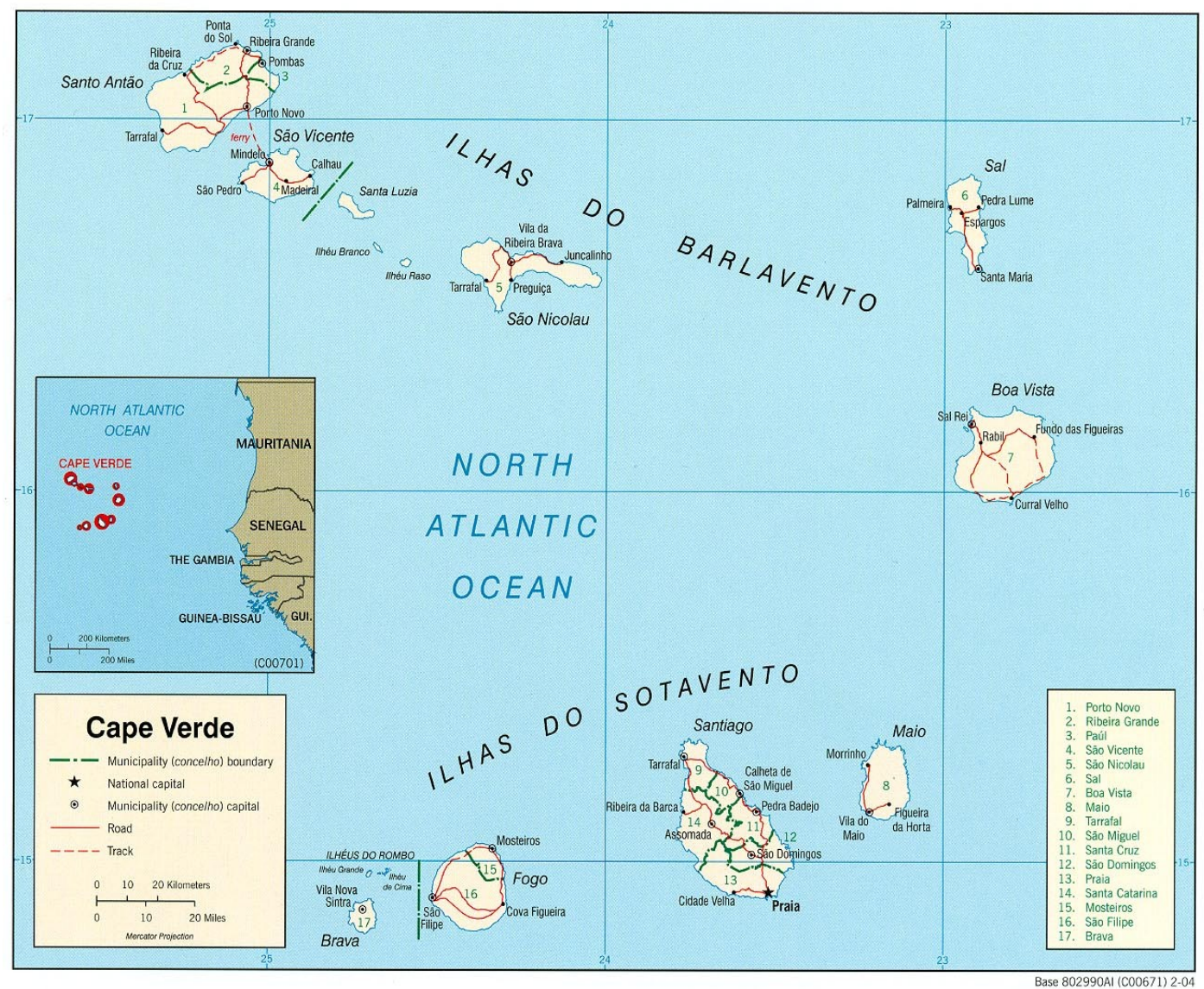

Mapa 1 - Localização das ilhas de Cabo Verde.

$\mathrm{O}$ modelo de colonização portuguesa em Cabo Verde procurou responder às particularidades do arquipélago, nomeadamente as dificuldades de território. ${ }^{2}$ Assim sendo, o caminho encontrado pela Coroa portuguesa para o início do povoamento foi a doação das ilhas, no caso de Santiago, para um nobre, o infante D. Fernando, por Carta Régia de 3 de Dezembro de $1460^{3}$, como "recompensa pelos serviços prestados ao rei e para aumentar a

2 DOMINGUES, Ângela. "Administração e Instituições: Transplante, Adaptação, Funcionamento". In: História Geral de Cabo Verde. Coordenação de Luís de Albuquerque e Maria Emília Madeira Santos. Lisboa: Centro de Estudos de História e Cartografia Antiga e Instituto de Investigação Científica Tropical; Praia: Direcção Geral do Patrimônio Cultural de Cabo Verde, 1991, v. I, p. 41 - 123.

3 CARREIRA, António. Cabo Verde: Formação e Extinção de uma sociedade escravocrata (1460 - 1878). Porto: Imprensa portuguesa, 1972, p. 19. 
riqueza da sua casa senhorial, em relação direta com a sua dignidade e prestígio social...". ${ }^{4}$ De sua parte, pelo ato da doação, o rei abstinha-se da árdua tarefa de povoar as ilhas, mas, como este mecanismo político era decisivo, concedeu ao donatário um conjunto de "privilégios", dentre os quais, a plena jurisdição sobre as terras doadas. ${ }^{5}$

Como é possível constatar, também a Carta de doação de D. Manuel, de 1497, à Dona Branca d'Aguiar, contraria os argumentos apresentados por Cadamosto. Nesta Carta de D. Manuel, a donatária tinha para além da exigência de contrair casamento digno, a de que somente os filhos varões herdassem. Segundo a vontade da Coroa, Jorge Correa, fidalgo $^{6}$ da Casa Real e de digna descendência, tinha a prioridade de escolha para o casamento. Tal doação, ao invés de romper com a descendência de Antonio de Noli, prolongou-a por meio de um casamento consentido pela Coroa. Por outro lado, com esta doação pretendia-se que os bens ficassem sempre na posse de um fidalgo protegido do rei. Nesta Carta de doação, a mesma teria os mesmos direitos, jurisdições e rendas da capitania da ilha de Santiago. Note-se uma sucessão imposta e limitada pelo casamento, tendo como objetivo resguardar a imagem do "descobridor" da ilha de Santiago e fidalgo da Casa Real. Esta imposição por parte da Coroa portuguesa garantia, para sempre a sucessão da capitania para os filhos e netos varões. ${ }^{7}$

Entretanto, o povoamento da ilha de Santiago foi grandemente comprometido, pelos fracos incentivos econômicos inicialmente propostos por D. Fernando e pela própria falta de colonos portugueses dispostos a irem viver na ilha, dada a longa distância de Portugal. Estes fatos somados a dificuldade de adaptação ao clima árido, a condições de

4 Id., Ibid., p. 42; 52: “Assiste-se (...) à recompensa de um grupo social: a nobreza, que serve o rei pelo exercício de cargos militares e administrativos".

5 CAETANO, Marcello José das Neves Alves. História do direito português (Fontes - direito público: 1140 - 1495). $3{ }^{\text {a }}$. ed., Lisboa: Ed. Verbo, 1992, p. 525 - 527. HESPANHA, António Manuel. História das Instituições: época medieval e moderna. Coimbra: Livraria Almedina, 1982, p. $101-106$.

6 Segundo as Ordenações Afonsinas, fidalgos são todos aqueles que descendem de "boa linhagem" até $4^{\circ}$. grau, herdando as boas maneiras, evitando a má conduta e do erro, por isso com vergonha da prática de conduta reprovável. Em outros termos, homem de bem (homem bom), mostrando tanto a nobreza como a bondade deve resguardar a prática de determinados atos. Esta "gentileza" se adquiria de três maneiras diferentes: por linhagem, como neste caso, pelo saber ou ainda por bondade. Ordenações Afonsinas, Liv. I, t. LXIII, §§ $6-8$ : “...filhos-dalgo devem ser escolhidos que venham de direita linha de padre, e de madre, e d'avoo atta quarto graao, a que chamam visavoos...."

7 ANTT, Chancelaria de D. Manuel, Livro 30, fl. 62, de 8 de Abril de 1497. Posteriormente, em 1536, Dom João, pela falta de filho legitimo de Belchior Correa, fidalgo da Casa Real, fez a doação da capitania da Ribeira Grande, com todas as rendas, jurisdições e direitos que o antigo Jorge Correa detinha, a João Correia de Sousa - ANTT, Chancelaria de D. João III, liv. 21, fls. 151v.-152 v. 
insalubridade e as epidemias e implicou no "atraso" da colonização do Arquipélago. Coube a D. Fernando encontrar fortes atrativos, preferencialmente econômicos, na tentativa de atrair indivíduos para a ilha de Santiago, estratégia que tinha sido empregada com sucesso nas ilhas da Madeira e dos Açores.

Além disso, devido à posição estratégica das ilhas, importante ponto de reabastecimento para o encontro marítimo da Índia e quase ao mesmo tempo para o estabelecimento de portos de trato, locais de comércio com as costas africanas, um esforço por parte da Coroa, no sentido de povoar a ilha de Santiago. Para tal, além da instalação de um acabou se impondo um aparelho jurídico-administrativo faziam-se necessários quadros para tornar seu funcionamento efetivo. Quanto a importância da ilha nos descobrimentos portugueses mais ao sul da costa atlântica africana acentuou-se a necessidade de povoá-la. ${ }^{8}$

Contudo, como exigência o armador deveria ter residência fixa na ilha de Santiago, mais precisamente na cidade da Ribeira Grande, por pelo menos quatro anos. ${ }^{9}$ Neste sentido, a donataria é consensualmente considerada como o principal instrumento para viabilizar a ocupação efetiva da ilha. Além de representar uma unidade econômica e jurídico-administrativa, a donataria distinguia-se por estar dissociada do patrimônio real, fazendo parte dos bens do donatário, com todos os direitos, rendas e jurisdições. $\mathrm{O}$ donatário agraciado, passava a exercer o seu domínio sobre as terras doadas e sobre os colonos, utilizando os poderes concedidos pelas jurisdições exceto: no que se referia às punições criminais e nas garantias legais dos colonos facultando-lhes apelar ao rei contra uma dada sentença do donatário. ${ }^{10}$

Ainda no que se refere a donataria é interessante salientar que as melhores terras da ilha de Santiago foram doadas aos donatários pela Coroa portuguesa, ficando grande número de trabalhadores agro-pastoris na qualidade de rendeiros, parceiros e meeiros. ${ }^{11}$

8 Carta dos moradores da ilha de Santiago - ANTT, Gavetas, 3-10-8. Ribeira Grande, Maio de 1510.

9 Pelas Cartas de cobrança de impostos devidos à Coroa, nelas se acham expressa que o armador é vizinho e morador na ilha de Santiago - ANTT, maço 8, Livro da receita da renda de Cabo Verde - anos de 1513 $-1516$.

10 DOMINGUES, Ângela, op. cit., p. 42.

11 Por rendeiros entende-se aqueles que arrendavam pequenas ou grandes dimensões de terras ao Morgado (a grande maioria) ou ao proprietário das mesmas, mediante um contrato feito na forma oral e sem nenhuma garantia, sujeitando-se aos caprichos do Morgado, que o podia expulsar quando bem quisesse. Parceiros são aqueles que se associam aos rendeiros, trabalhando a terra à custa do seu trabalho, dos familiares ou quer ainda pela entreajuda no seio da comunidade (djunta mon). Possuíam insignificantes parcelas de terras e praticavam essencialmente uma agricultura de subsistência. 
Melhor explicando: com o aparecimento dos morgadios, as terras foram arrendadas de ano em ano aos rendeiros que, por vezes, eram expulsos arbitrariamente das mesmas após o término das colheitas. Por isso, os rendeiros não se empenhavam para tirar da terra todo o seu potencial. O mau aproveitamento das terras permeou o surgimento de parcelas de terra incultas. Ademais, os abusos de poder institucional e simbólico eram identificados como o principal responsável pela miséria dos rendeiros, parceiros e meeiros.

Não parece desmedido acrescentar que o poder senhorial contava com um forte privilégio que conferia perpetuidade à doação, característica apontada, por António Pusich, como sendo o principal instrumento de defesa de privilégios e de concentração do poder em mãos dos morgados, bastante evidente na irracionalidade e despropósito do mando sobre os trabalhadores rurais.

Segundo o modelo de capitanias hereditárias, a ilha de Santiago foi dividida em duas partes: a do sul, centrada na Ribeira Grande, e a do norte, sediada em Alcatrazes, confiadas por D. Fernando ao navegador genovês António de Noli e a Diogo Afonso, respectivamente, como "recompensa" pela "descoberta". ${ }^{12}$ Como "capitães-donatários", passaram a deter um cargo hereditário que lhes outorgou o direito de "assegurar o povoamento, de repartir a terra em regime de sesmarias, de organizar um sistema administrativo...". Dom Manuel concedeu a Rodrigo Afonso amplos poderes sobre a capitania doada. ${ }^{13}$

A Carta de doação feita por D. Manuel a Rodrigo Afonso, reservava para a Coroa portuguesa o direito de decisão sobre a pena de morte ou a mutilação de membros. Ainda obrigava o donatário a conceder terras a quem julgasse ter melhor condição para explorálas, o que deveria ser feito em um período de cinco anos, sob pena de as terras serem confiscadas e arrendadas para outra pessoa. Em outros termos, a doação configurava um direito adquirido sob a forma de benefício, mas sempre respeitadas as condições impostas pela Coroa portuguesa.

A excessiva concentração do poderio político e económico nas mãos de poucos foi sempre uma das características marcantes do sistema administrativo local em Cabo Verde,

12 FURTADO, Cláudio Alves. Transformação das Estruturas Agrárias numa Sociedade em mudança Santiago Cabo Verde. São Paulo, 1988. 357 f. Dissertação (Mestrado em Sociologia) - Faculdade de Filosofia, Letras e Ciências Humanas, Universidade de São Paulo, p. 23. Infelizmente não dispomos nos arquivos portugueses desta Carta de doação. Entretanto, temos a doação feita a Dona Branca d'Aguiar, filha de Antonio de Noli, deduzindo-se a partir desta, a forma possível da dita Carta.

13 ANTT, Livro das Ilhas, fl. $69 \mathrm{v}$. 
desde os primórdios do seu povoamento. Em 1824, os cargos administrativos de menor relevância nas Câmaras eram ocupados por pessoas sem escolaridade formal, o que facilitava sua manipulação, mediante suborno, por parte dos monopolistas e traficantes. Ademais, os juizes ordinários, responsáveis pelas sentenças, mal sabiam assinar o nome e eram assessorados, na maior parte das vezes, por degredados que representavam os interesses dos traficantes.

Ao apresentar o estado da atual administração nas ilhas de Cabo Verde, em 1824, António Pusich destacou a parcialidade da administração local, manipulada por monopolistas e traficantes de escravos. Não deixou ainda de notar que os seus funcionários eram constituídos por degredados, os quais aplicavam as leis unicamente para favorecer os interesses de ricos morgados.

As Cameras destas Ilhas quaze sempre cumpostas de homens ignorantes, ou degradados; por que os que melhor podiam occupar estes Cargos, ou responsabilidade ter ás suas Ordens uma Camera venal, ignorante, ou mal intencionada, e dar-lhe com a sua occulta influencia, bem como de um autômato o movimento que lhes paresse: o que he muito fácil de conciguir n'aquellas Ilhas, cujos habitantes ou aquella desgraçadamente, aprendem a moral Publica, ou fugitivos monopolistas, e traficantes, que elludem dos rusticos com promessas fantásticas e atrahem os degradados com peitas, e sobornos; da que resulta que muitas destas Câmeras não se juntam para as vereaçoens nos dias da Ley; nem cuidam do bom regimento da terra; mas as mais das vezes são convocadas para fabricarem nos abaixo assignados, attestados e protestos contra as Autoridades que querem coibir os excessos dos monopolistas e traficantes, e nessa mesma occazião são animadas com copos de agoardente, e mil promessas: d'aqui se pode coligir quaes serão as Sentenças de semelhantes Juizes Ordinarios, e dos quaes uma grande parte mal sabem assignar o seu nome, e não tem por Acessores se não algum Rabúla, ou degradados práticos dos traficantes (...). ${ }^{14}$

Na verdade, as câmaras municipais estavam nas mãos de indivíduos nascidos na ilha - "e chegou a terra (ilha de Santiago) a taes termos, que quantos há hoje na Camara saõ crioulos". 15

Os poderosos detinham assim grandes poderes e influência sobre a justiça e as câmaras municipais. Por sua vez, a ausência de juizes facilitava a concentração de poder por parte de homens, como Domingos Ramos Monteiro, Nicolau dos Reis e Manuel

14 AHU, Cabo Verde, Cx. No. 077/ Doc. N. 95-A, de 1824.

15 ARSI, Lus., cód. 74, fls. 141 - 143 v., de 27 de Junho de 1617. 
Tavares Homem. Os juizes poderiam representar uma barreira quase intransponível para os proprietários, tendo em vista que à luz das legislações, os morgados teriam, por exemplo que elaborarem contratos de arrendamento por escrito, o que na maioria dos casos não acontecia. Por outro lado, a presença do magistrado deveria implicar, na investigação das diversas condutas discricionárias dos morgados, como as sucessivas violências perpetuadas contra os rendeiros. Por tudo isto, evitavam a todo custo a presença de magistrados, o que facilitava a manipulação de oficiais, reduzidos a meros executores de seus interesses. ${ }^{16}$

Pelo exemplo da disputa de Joze dos Santos Landim pelo morgadio de Pico Vermelho, um dos mais ricos da ilha de Santiago, pode-se compreender a inoperância da justiça local, sempre atrelada aos interesses dos morgados. Landim reclamava junto do governo geral a falta de imparcialidade da justiça e os abusos cometidos contra ele, bem como a existência de "paixões particulares" ao invés da aplicação das leis e da razão. Apesar da sentença proferida pela justiça da Câmara ter estabelecido que António Correa Landim não dispunha de qualquer bem no referido morgadio, este continuava pressionando e interferindo na administração do referido vínculo, afrontando seu legítimo proprietário. ${ }^{17}$

O surgimento, desde 1821, de um projeto "revolucionário" em Portugal foi decisivo para reivindicação de um conjunto de reformas das câmaras municipais, em mãos de monopolistas e traficantes. Pela carta enviada de Lisboa pelo Tenente de Infantaria, Jose Antonio Serrão, ao coronel governador militar da ilha de Santiago, Gregório Freire de Andrade, de 1838, sabe-se que havia um projeto de revolução em Portugal que, por sua vez, deveria ser posto em prática em Cabo Verde. A carta também revela que os liberais exaltados mantinham contatos com integrantes do partido em Lisboa.Por ser um dos líderes do partido dos "revoltosos", o referido tenente foi transferido para Lisboa.

Além disso, a revolta política em Cabo Verde devia-se, sobretudo ao menosprezo da Coroa perante o período de fome registada em Cabo Verde, o que levou a administração colonial a não pagar os funcionários. Tal deliberação administrativa levou ao descontentamento da elite política local. Sabe-se que durante a fome de 1831 e 1833, o governador geral Costa Macedo solicitou socorros à Coroa portuguesa que, por sua vez, não atendeu ao apelo. Os índices de mortalidade gerados pela fome só não foram maiores porque, em 1834, oito navios norte americanos, atendendo aos apelas do então governador

16 AHU, Cabo Verde, Cx. No. 060/ Doc. N. 3, de 24 de Janeiro de 1812.

17 AHU, Cabo Verde, Cx. No. 049/ Doc. No. 9, de 4 de Março de 1796. 
geral Manoel Antonio Martins, distribuíram gêneros alimentícios para populações das ilhas, chegando a atender por volta de 40 mil pessoas. Segundo o ofício, a prefeitura teve que tirar dos seus próprios cofres três contos de reis para pagar o frete desses navios, sem qualquer apoio e reconhecimento por parte da Coroa portuguesa, que havia "abandonado" o arquipélago à sua sorte. Por isso mesmo, o referido prefeito, a par da "ingratidao" de Sua Magestade, o rei de Portugal, dirigiu uma carta de agradecimento ao governo dos Estados Unidos pela "esmola". ${ }^{18}$ Para os liberais exaltados o flagelo da fome de 1831/1833 foi interpretado como punição dos crimes do governo geral anterior, e que impediram a "sonhada revolução". O prefeito ainda considerava que os "cidadãos" dos Estados Unidos da América salvaram em 1832 a maior parte dos habitantes das ilhas de Cabo Verde. Não por acaso, a prefeitura, em sinal de reconhecimento, tenha concedido várias regalias a esses comerciantes. Além disso, era a única "nação" que continuava a comprar produtos e manufaturas de Cabo Verde. A leitura desse ofício permite compreender o descontentamento das elites políticas locais quanto a omissão da Coroa portuguesa perante a fome.

Por essa razão, determinou-se que todas as mercadorias provinientes dos EUA passariam a gozar direitos nos portos de Cabo Verde, em sinal de reconhecimento pelo gesto. Os corregedores norte americanos vinham pagando impostos de $12 \%$, ao invés de $24 \%$, nas alfândegas do arquipélago. Segundo o ofício, "Se agora se puzer a Pauta em vigor (...) conservando-se os mesmos direitos de 24\%, os primeiros Corregedores Americanos (...) terão logo de pagar direitos duplicados do que antes pagavão". Porém, mantiveram-se cauteloso diante da possibilidade dos navios americanos deixarem de frequentar os portos do arquipélago, reclamando dessas medidas administrativas: "Hé esta a maneira por que vos outros, Colonos portugueses, galardoaes a quem vos salvou a existencia d'entre as garras da morte?". Também o próprio prefeito reconheceu que os colonos começavam a romper com a antiga "raça estúpida da colónia", onde o inglês, pela necessidade de comunicação com os americanos do norte, era mais conhecido do que a própria língua portuguesa. $\mathrm{O}$ ofício demonstra que os navios americanos frequentavam continuadamente os portos de Cabo Verde, responsáveis pela difusão de ideiais reformadores em várias ilhas. No imaginário coletivo dos habitantes de Cabo Verde, os

18 Os navios norte americanos aportavam frequentemente os portos cabo-verdianos para fazer transações comerciais. Devido ao comércio com o arquipélago, tinham uma representação consular na vila da Praia. 
norte americanos passaram a ser vistos como salvadores e libertadores, e suas chegadas aos portos cabo-verdianos representavam a libertação e a salvação das práticas tirânicas dos sucessivos governos. A fome ganhou novos significados com as disputas políticas e ficou associada aos sinais do fim do mundo e a vinda dos anticristos. ${ }^{19}$ Por isso, os rendeiros deveriam se armar para combater a opressão dos morgados.

Essa perspectiva foi reforçada por outro depoimento que além de denunciar o desprezo por parte da Coroa, confirma a existência de benefícios concedidos a alguns dos escolhidos dela. Fica evidente o medo das populações por conta das ações das autoridades de Cabo Verde. Não resta dúvida acerca da displicência das autoridades que importaram pequenas quantidades de gêneros de primeira necessidade como o milho. Delegavam esta responsabilidade à população, sendo que muitos indivíduos vendiam panos de seda nos portos ou mesmo terras por pequenas quantidades de arroz e de milho. ${ }^{20} \mathrm{O}$ fato da documentação ter destacado que os rendeiros não quiseram trabalhar as terras, demonstra que os mesmos deram-se conta que a parca colheita conseguida dava unicamente para pagar as rendas atrasadas das terras e comprar algum mantimento.

Esta fala oficial revela a emergência e o poder político de uma elite local. Um primeiro exemplo referia-se a Gregório Freire de Andrade que, além de comandante da infantaria da ilha de Santiago, rico proprietário rural, reverendo da igreja católica no interior da ilha, detinha grande influência político-religiosa sobre as suas populações, principalmente sobre os rendeiros. Um segundo referia-se Marcelino Rezende Costa, escrivão da Junta governativa desde 1829. Considerado pelo prefeito de Cabo Verde, Manoel Antonio Martins, como o principal responsável pelas intrigas, exercia grande influência política na ilha de Santiago, ao ponto de levar o mesmo governante a considerar que "aumentava a confuzão para ter maior numero de infelizes, que dependessem delle". Reiterou os atentados que fora vítima, em 1832, quando sua residência era frequentada "unicamente dos liberais mal olhados, e mal olhados eu mesmo pela Junta". Não deixou de destacar a grande conspiração política dos "sectarios Baptista" que, na noite de três de Julho de 1832, "tomaram uma attitude marcial contra huma sonhada revolução de que me apelidaram chefe". O poderio político de Gregório Freire d'Andrade foi reforçado com a sua nomeação, em 21 de dezembro de 1835, para o cargo de administrador do concelho de

19 Aqueles que cometiam injustiças.

20 Boletim Officiall do Governo Geral de Cabo-Verde, NNo 119, de 27 de Dezembro de 1845, p. 480. 
Santa Catarina. O referido ofício permite-nos compreender o exercício do poder político no interior da ilha. O morgado e comandante da infantaria da ilha de Santiago "obteve maior numero de votos para administrador deste concelho".

Ainda segundo Martins, tanto Gregório Freire de Andrade quanto Marcelino Rezende Costa perseguiam os seus inimigos políticos, principalmente "todos quantos contradiziam, ou simplesmente censuravam os seus desatinos". O fato dos liberais exaltados dirigirem "insultos a indivíduos conhecidos por seu liberalismo", mostra o descontentamento quanto às opções políticas postas em prática. Também os considerou como "negros terroristas" que em alguns casos fizeram com que a Junta da Fazenda procedesse a "devassas", "calumnias", roubos de propriedade, bem como "apoiar contrabandos". Além disso, começaram a ser promovidos para cargos públicos tanto "degredados turbulentos" quanto "mulatos bébados", desprezados pelos anteriores governos. Tais iniciativas representavam um conjunto de mobilizações políticas, para a promoção dos simpatizantes da elite local, como também a consciência de que a introdução do liberalismo no arquipelago não resultou na plena liberdade dos seus habitantes.

Estes fatos atestam que tanto Marcelino quanto Gregório Freire de Andrade detinham grande influência e confiança não só de determinados morgados, como principalmente dos rendeiros, a ponto de os mobilizar politicamente contra os seus morgados. Não é por acaso que Manoel António Martins os denominou de "terroristas", tendo em vista as suas maquinações políticas contra o regime liberal implantado em Cabo Verde. Ademais, para o então prefeito, as iniciativas dos referidos políticos era "bifronte". ${ }^{21}$ Se de um lado, apoiavam os morgados que eram seus aliados políticos; de outro mobilizavam os rendeiros a rebelarem contra os morgados que eram seus adversários políticos, fazendo crer aos primeiros que deveriam denunciar todos os abusos que vinham sofrendo dos mesmos proprietários. Todos os morgados que discordassem das decisões políticas eram perseguidos. Para tal, esses políticos faziam crer aos rendeiros que deveriam se mobilizar para contestar a ordem político-econômica vigente, pois que a nova Constituição protegia os seus direitos.

Esses exaltados também exigiam da prefeitura profundas reformas políticas, com destaque para a realização periódica de eleições dentro das freguesias. Para atender às pressões, por meio do ofício de 31 de maio de 1834, o então prefeito considerou que os

21 Que tem duas frontes e caras, falso, traiçoeiro. 
seus esforços e empenho para garantir a eleição dos deputados às Cortes com a maior liberdade objetivavam servir a "pátria portuguesa". Para tal, destacou o papel de D. João VI, por ter castigado os tiranos, os "malvados e os seus crimes", bem como sabendo procurar nos seus "domínios" pessoas que servissem o bem público. Considerou os flagelos da fome e da miséria em Cabo Verde, principalmente nas ilhas de sotavento, como resultado da tirania e prevaricações dos seus funcionários, vista com "desprezo" pela Junta da Fazenda, dentre os quais destacava Marcellino Resende Costa, considerado um adulador. Segundo este tais atitudes demonstraram como os tiranos viam a miséria dos povos, nada mais que "escravos" dos seus caprichos. Também resultou na perseguição dos "sectarios" de Baptista aos liberais moderados, dentre os quais o então prefeito.

Entretanto, as divergências políticas não se limitavam ao calendário eleitoral, como também à melhoria das condições de vida das camadas sociais mais pobres e exploradas. Um dos exemplos dessas confrontações políticas verificava-se, por meio das participações dirigidas à Coroa portuguesa. Foi assim que o Conde da Póvoa, enquanto Ministro, Secretário de Estado dos Negócios da Fazenda e presidente do Erário régio, de 14 de Fevereiro de 1833, determinou à Junta governativa o envio da "Rellação da quantidade da urzella que existia em cada huma dellas", bem como a capacidade de produção anual de todas as ilhas. Este governante questionou a demora no envio da relação, em descumprimento a uma ordem régia, que visava recolher subsídios para melhorar a produção da urzela em Cabo Verde. A Junta deveria dar cumprimento a essa ordem enviando uma declaração sobre as vantagens ou prejuizos resultantes à Real Fazenda durante a administração de Manoel Antonio Martins, bem como em relação à sua administração. Aproveitando desta determinação, Marcellino Rezende da Costa, na qualidade de escrivão, deputado da Junta da Administração e Arrecadação da Fazenda Pública e um dos Fiscais dos bens da Coroa no arquipélago, dirigiu uma representação à Coroa portuguesa contra Antonio Manoel Martins, administrador do contrato da urzela em Cabo Verde, de 24 de Outubro de 1833, acusando-o de "mao comportamento" em relação aos bens da Coroa. Este administrador, como parte da estratégia política para enfraquecer o poderio político-econômico de Martins, determinou por meio de circular dirigido tanto às câmaras municipais quanto aos feitores, a afixação de editais "nos lugares mais publicos", com a lista de todos os urzeleiros do arquipélago. Segundo este, a publicação desta lista resultaria em grande "beneficio", tendo em vista de "virem a receber para o futuro dinheiro 
sem ser admissivel outro genero em pagamento de venda". Tanto as câmaras municipais quanto os feitores deveriam aceitar queixas, representações e denúncias contra o referido contratador, devendo ser remetidas à administração da fazenda, por escrito, registradas nos "Livros competentes" das câmaras municipais. Tal iniciativa política obteve apoio dos deputados Antonio de Brito do Lago, Joze da Silva Pereira e Ambrozio Gomes de Carvalho.

Por outro lado, para fazer face às mobilizações partidárias e das rebeliões daí decorrentes, a prefeitura lançou mão de um conjunto de medidas político-administrativas. Por meio da mesma portaria, o referido Conde homologou a determinação do prefeito Manoel Antonio Martins, de 23 de julho de 1834, por meio da qual designou provedores para todos os distritos do arquipélago. Martins nomeou para a vila da Praia e Santa Catarina dois de seus principais aliados políticos, Nicolau dos Reis Borges e Luiz Freire de Andrade respectivamente. Dessa nomeação ficou de fora Gregório Freire de Andrade, principal opositor político e um dos que ambicionava o cargo de provedor de justiça. Não é por acaso que este político incitou os rendeiros a revoltarem contra Nicolau dos Reis, na qualidade de morgado de Achada Falcão. ${ }^{22}$

Os adversários políticos de Martins eram, grande parte, seguidores de Baptista ${ }^{23}$, na maioria dos casos formados de liberais exaltados, eram conhecidos em Cabo Verde como um dos grandes defensores e promotores do abolicionismo, divulgando doutrinas religiosas contra a escravidão e o monopólio. Fizeram crer aos rendeiros que a Bíblia justificava todas as suas ações de rebeldia contra os seus morgados e que perante Deus eram criaturas com direito à plena liberdade. Além disso, que os rendeiros não deveriam trabalhar para os "lobos cruéis" (Atos, 20: 29 - 30), sob pena de serem castigados por Deus, com a perda de suas almas. Ao falar sobre a salvação, os seus seguidores salientaram a presença dos falsos profetas. Segundo eles, “E não é maravilha, porque o próprio Satanás se transfigura em anjo de luz. Não é muito, pois, que os seus ministros se transfigurem em ministros da justiça; o fim dos quais será conforme as suas obras" (2 Coríntios, 11:13 - 15). Para eles, a Bíblia reduz o mundo ao maligno. Por isso, ao se submeterem aos desmandos dos morgados, os rendeiros estariam seguindo as obras do demônio - "Sabemos que somos de

22 AHN, $S G G$, Portarias do Ministério do Reino (Janeiro - Dezembro/1834). Originais manuscritos, Cx. 285.

23 Secretário de D. Duarte, governador geral de Cabo Verde em 1830. 
Deus e que o mundo inteiro jaz no Maligno". Acreditando num breve retorno de Cristo, faziam crer aos rendeiros que deveriam apartar-se de tais práticas, como inscrito no livro de Apócalipse, 18: 4 - "Retirai-vos dela, povo meu, para não serdes cúmplices em seus pecados e para não participardes dos seus flagelos". Os rendeiros deveriam estar vigilantes quanto às suas práticas, pois "Vigiai, pois, porque não sabeis quando virá o dono da casa: se à tarde, se à meia-noite, se ao cantar do galo, se pela manhã, Para que, vindo ele inesperadamente, não vos ache dormindo. O que, porém, vos digo, digo a todos: Vigiai", (Marcos, 13:35-37).

Dentre as principais vítimas de Baptista, António Manoel Martins destacou o nome de João Joze Antonio Frederico, ex-tesoureiro da Junta da Fazenda. Em 1831, foi forçado por este segmento político a abandonar a sua casa e a sua família, aonde não regressou até 1834, quando da instituição dos corpos administrativos da prefeitura da província de Cabo Verde e Guiné. Segundo o mesmo prefeito, tratar-se-ia de "hum dos filhos destas Ilhas, em que se encontra mais illustração, á qual reune conhecimentos locaes da Prov ${ }^{a}$, e que as suas virtudes civicas são geralmente reconhecidas". Como forma de reparação política, pediu ao prefeito de Cabo Verde o cargo de sub-prefeito da camara da Guiné, somando ao pedido feito também pelo Coronel Joaquim Antonio de Mattos que, segundo Martins, fez “penozos (...) sacrificios a prol da cauza das Liberdades Patrias". A estratégia política de Baptista consistia na perseguição e na expulsão do arquipélago de todos aqueles que se opusessem às medidas administrativas tomadas pelo governo geral.

Além das perseguições políticas aos liberais moderados, os exaltados exigiram da prefeitura a urgência da apresentação dos deputados junto às Cortes, em Lisboa. Tal mobilização fez com que o prefeito, para atender às pressões políticas das várias freguesias do interior da ilha de Santiago, procedesse à contratação de uma embarcação para essa finalidade. Tal prática revela que os habitantes do interior da ilha de Santiago, organizados em torno do partido separatista, vinham pressionando politicamente para que as autoridades realizassem eleições periódicas em Cabo Verde, como parte das reformas políticas. Caso contrário, subverteriam a ordem política vigente, como também inviabilizariam a governação da província, não reconhecendo as suas determinações. A própria preocupação do governador geral, Marinho, quanto à realização urgente da eleição, atesta as pressões políticas que vinha sofrendo não só por parte dos representantes das demais ilhas, como também dos morgados do interior da ilha de Santiago. 
(...) Sendo eu dado em Setembro ultimo as ordens mais pozitivas para se reunirem os Elleitores das Ilhas em São Thiago no primeiro de Novembro, nem huma so camara das outras ilhas satisfazer aesta ordem, foi precizo eu trazer commigo, e hir pessoalmente buscar os elleitores de Santo Antão, S. Vicente (...) São Nicolao, Boa Vista (...) da Ilha do Maio, os do Fogo, e Brava ainda não chegaram apezar de ter mandado lá uma embarcação para este fim, e julgo ser precizo mandar outra com hum official. He tãobem a cauza desta apathia a execessiva pobreza das Camaras Municipaes, e da maior parte dos habitantes, e em todas as Ilhas não haver embarcações capazes de soffrerem as fortes tensões dos ares neste Arquipelago $(\ldots)^{24}$

Entretanto, as disputas políticas por ocasião da realização das eleições para cargos políticos nas freguesias levaram as populações da ilha de Santiago a revoltaram-se contra algumas arbitrariedades do prefeito de Cabo Verde. Uma dessas revoltas ocorreu, devido aos saques realizados pelo prefeito de Cabo Verde na casa de Antonio Pereira da Borja. Este político era conhecido como um dos principais apoiantes do regime constitucional em Cabo Verde. Político e comerciante, era declaradamente um liberal exaltado, o que motivou a revolta dos seus aliados contra a prefeitura. Em resposta registou-se uma grande mobilização política para forçar a abdicação do cargo do então prefeito de Cabo Verde. ${ }^{25}$ Martins, utilizando de seu poderio político, determinou a utilização da violência contra os seus opositores políticos, na maioria dos casos, compostos de liberais exaltados.

Para o mesmo prefeito, tais mobilizações políticas deviam-se, sobretudo às reformas políticas levadas a cabo pela prefeitura, que tem "cauzado grande regozijo no mizeravel povo, cuja voz não pode passar álem do Atlantico, mas tem-me suscitado novos inimigos nos opulentos Feotas, que chupavam as substancias do povo, contudo não desanimo". Fica evidente que para o prefeito de Cabo Verde o exercício do poder político não permitia quaisquer manifestações de descontentamentos da população. Para tal, este estava determinado a promover um conjunto de reformas político-econômicas para derrubar o regime de monopólio vigente no interior de Santiago. Por conta disso implementou duas importantes reformas administrativas: substituiu os comandantes militares, os principais

24 AHN, $S G G$, Ofícios expedidos ao Ministério e Secretaria de Estado da Marinha e Ultramar (1830/Abr/02 - 1836/Jan/13). Cópias manuscritos. Liv. 520, fl. 220.

25 AHN, $S G G$, Ofícios expedidos ao Ministério e Secretaria de Estado da Marinha e Ultramar (1830/Abr/02 - 1836/Jan/13). Cópias manuscritos. Liv. 520, fl. 191. 
responsáveis pelo regime de monopólio, em todas as ilhas pelos provedores de justiça, câmaras municipais e juizes da paz. E depois determinou a redução dos efetivos militares e das milícias, substituindo-os por uma "Guarda Nacional”, que teria melhores níveis de instrução e preparação. Tais iniciativas políticas da prefeitura revelam a incompatibilidade do cargo militar com o regime liberal. Também granjeava antipatias e receios dos principais capitães militares, dentre os quais cabe destacar Gregório Freire de Andrade. Além disso, revela que os rendeiros estavam inteiramente excluídos dos centros de decisões políticas.

Um desses exemplos é a proposta de criação de uma "companhia mercantil", de 28 de junho de 1834, com o objetivo de "levar esta (...) Colonia ao ponto de poder ressarcir á Metropole a perda do Brazil". A companhia, aproveitando-se da boa situação geográfica do arquipélago, deveria ser capaz de articular os interesses do Estado e dos respectivos sócios proponentes. Carecia ser composta de capitalistas e de "pessoas mais acreditadas" das ilhas. Propunha-se também a fazer com que o monopólio do comércio com as ilhas fosse assumido pelos portugueses e não, como vinha acontecendo, pelos estrangeiros. Não é por acaso que no art. $5^{\circ}$ da ata da fundação, além de determinar que só pudesse ser seus acionistas os "portugueses natos" ou "estrangeiros naturalizados em Portugal, e Seus Dominios", também predispõe que os estrangeiros não teriam direito ao voto. Também tinha como objetivo garantir o desenvolvimento das ilhas com os grandes lucros da companhia. Para a escolha do presidente, procuradores e deputados, determina pelo $\operatorname{art}^{\mathrm{o}} .6^{\mathrm{o}}$ que fosse realizada uma "votação feita por Escrutinio Secreto em Listas de sete nomes". A companhia teria sob sua incumbência a administração das ilhas, nomeando para tal um administrador geral da colónia, coadjuvado por um diretor geral de finanças. Pretendia ainda manter a administração municipal, com ressalva que as câmaras deveriam nomear anualmente seus procuradores à junta geral da província. Para resolver as contendas deveria haver um magistrado nomeado pelo governo com o poder de fiscalização da administração. Para a defesa das ilhas, poderia nomear um governador militar subordinado às ordens do administrador geral da colonia. A arrecadação de impostos e tributos ficaria sob jurisdição da companhia, bem como a importação estrangeira.

A companhia tinha com obrigação, "promover a cultura, indústria, Artes (...) e tudo quanto for para a prosperidade, e Civilização dos Povos". Só ela poderia proceder à distribuição das terras em regime de "sesmarias", aplicando os despositivos da Ordenação Afonsina, L. IV, t. 43, como também procedendo à distribuição de sementes a todos os 
agricultores. Obrigava-se ainda a promover a extinção da escravatura como meio eficaz para a "Civilização e prosperidade daquelles Povos". O tráfico de escravos era ruim ao olhos do novo regime político-econômico, uma vez que a falta de braços para a lavoura seria "mal suppridas com braços enervados pelos grilhões da escravidão". Tendo em conta que as leis anteriores não abarcavam os casos de "suspeição", a Coroa portuguesa deveria aprovar uma nova lei, proibindo todo tipo de tráfico de escravatura e sem subterfugio, impondo penas pesadas àqueles que se dedicarem à "tão abominavel navegalção". Deveriam ainda sofrer penalidades todos os casos de suspeitas bem fundamentadas em "vestigios permanente", uma vez que toda a fiscalização tinha sido delegada às embarcações norte-americanas. Os liberais moderados defendiam a rápida transição de uma agricultura tradicional para uma agricultura voltada para o comércio, o que possibilitaria romper com o parasitismo dos morgados do interior da ilha de Santiago.

$\mathrm{Na}$ prática, as reformas políticas propostas reconduziram os morgados mais influentes da ilha ao poder. Um desses exemplos se verificou com a nomeação do coronel de milícias Joaquim Joze Pereira para o cargo de recebedor geral de Cabo Verde em 1834. Para o prefeito Manoel Antonio Martins, além de ser um "rico proprietario, Capitalista, $e$ Negociante da ilha de São Thiago", o candidato foi funcionário da extinta Companhia Grão- Pará e Maranhão ${ }^{26}$, "respeitado dos grandes, venerado dos pequenos". Como condição, o negociante pediu para nomear os seus secretários, “cuja escolha recahio com effeito nos dous mais habeis sujeitos deste paiz". Ainda para Martins, tornava-se indispensável que a receita de Cabo Verde correspondesse às despesas, o que não vinha se registrando desde 1819, quando o deficit entre 18 e 20 contos de reis. A comissão financeira teria como principal desafio o de regularizar a confusão existente, reduzir a cobrança de impostos com pequenos acréscimos nos rendimentos, sem os “immensos vexames, de q. os povos tem sido aliviados".

Também propôs a nomeação de Antonio dos Santos Chaves Júnior para a recebedoria, por ser "Negociante de grande crédito". Para pagar os empregados, o referido prefeito devia, ao invés de fazê-lo em gêneros, como era prática, efetuá-lo com dinheiro. Tal medida se impunha, tendo em vista que os valores dos gêneros eram irreais, muitas das vezes excedendo o valor dos salários.

26 Antiga companhia mercantil que, em finais do século XVIII, detinha o monopólio da administração de Cabo Verde e costa da guiné. 
Como parte das reformas, o mesmo prefeito denunciou à Coroa portuguesa, por meio do ofício, de 9 de julho de 1834, o fato de estar a ser "incomodado com queixas contra os juizes leigos", segundo as quais praticavam injustiças "mais atrozes, mais vexatorias", mediante despachos dos "mais absurdos". Quando eram arguidos em processo por tais excessos, reiteravam que eram leigos, "que nada entendem do Processo Antigo, $e$ muito menos do Moderno". Sustentavam ainda que não eram responsáveis pelos "effeitos da sua ignorancia". Porém, para o prefeito, tais argumentos constituía pretextos encobertos por malícia. Tendo em vista que não poderia passar por tal desordem, tendo em vista que o Poder Judiciário era, pela Constituição, independente do Poder Executivo, a Coroa portuguesa deveria fazer entrar em funções os magistrados legalmente nomeados. Tal ignorância dos juizes fazia com que fossem facilmente manipulados pelos credores, os quais aproveitando da miséria geral dos rendeiros do interior da ilha obtinham penhoras de prédios que valiam de 10 e 12 vezes mais que o montante das dívidas. As dívidas colocadas em praça no tempo da pobreza, eram arrematadas pelos credores. Em resposta a tais “infracções das Leis naturaes, civis, e sociaes", o prefeito determinou a ilegalidade de tais arrematações, ficando os credores com o "jus de se indemnizar das suas dividas pela única maneira". Segundo Manoel Antonio Martins, tal medida administrativa foi recebida com contentamento pelos "despojados colonos", que limitavam a mendingar "o pão quotidiano á porta dos mesmos predios, que dantes os sustentavão, e que a usura lhes havia arrebatado com a mais enorme lizão". Porém, ao invés de uma simples substituição dos detentores de cargos políticos, os liberais exaltados exigiam reformas políticas profundas no governo geral, possibilitando que todos os cidadãos podessem ser candidatos a cargos políticos.

Por outro lado, Martins levou avante um conjunto de iniciativas legais contra os seus oponentes, constituído por liberais exaltados. Em primeiro lugar reapresentou o "lebello" do ex. secretário do governo dirigido por Antonio Marques da Costa, em que acusou Gregório Freire de Andrade, enquanto Coronel de Milícias, de ser "suspeito em huma Participação dirigida a V. Mag.e Imperial". Para reforçar a acusação reafirmou que “Cumpre-me assegurar a V. Mag.e Imperial, que tudo quanto allega o Ex-Secretario são verdades incontestáveis, e aqui geralmente sabidas". Em segundo lugar, destacou que Marques da Costa sempre manteve uma intíma ligação com os partidários do regime liberal em Cabo Verde a ponto de ser considerado pelo ex-governador, D. Duarte, não só como 
conselheiro daquele partido no arquipélago, como também um dos "principaes agentes da revolução de 23 de Setembro de 1833”. Figura destacada no Brasil, em Lisboa e em Cabo Verde, ficou conhecido como um liberal exaltado. Detinha profundos conhecimentos da literatura, legislação, diplomacia, bem como "conhecimentos locaes", por ter sido um dos dirigentes dos negócios do arquipélago durante dez anos. Segundo Martins, justificava-se a sua nomeação para Delegado do Procurador Régio, ainda mais tendo em vista a "falta de homens habeis nesta Provincia". ${ }^{27}$ Martins propunha que para cargos públicos deveriam ser indivíduos reconhecidos como sendo liberais e favoráveis às reformas políticas em curso no arquipélago, como é o caso de Joze Joaquim Lopes de Lima. Em terceiro lugar, determinou por meio do ofício $\mathrm{n}^{\mathrm{o}} 22$, de 30 de junho de 1833, que todas as câmaras municipais redobrassem os esforços para que "as Eleições se concluão com a mais brevidade possivel, attentas as dificuldades que offerece a distancia em que se achão huãs das diversas partes de que a mesma Prov. ${ }^{a}$ se constitui”. Pelo quadro a seguir pode-se constatar que foram nomeados para cargos administrativos indivíduos que, além de ser integrantes do partido Liberal, também eram militares, ricos proprietários e comerciantes em Cabo Verde.

\section{Figura 1 - Quadro do Corpo administrativo de Cabo Verde proposto pelo prefeito Manoel Antonio Martins (1834 - 1835)}

\begin{tabular}{|l|}
\hline \multicolumn{1}{|c|}{ CORPO ADMINISTRATIVO DE CABO VERDE (1834) } \\
\hline \multicolumn{1}{|c|}{ Para Conselheiros da Prefeitura } \\
\hline $\begin{array}{l}\text { Peral das Alfândegas nomeado; e o Honrado Coronel de Milicias Joaquim Joze } \\
\text { Pereira, da Ilha de S. Thiago, que serve actualmente de Recebedor Geral Interino, } \\
\text { homem de Concelho, e de virtude, amante da Lei, e izento de Paixões; conhecedor } \\
\text { do Paiz, e bom Agricula. }\end{array}$ \\
\hline \multicolumn{1}{c}{ Para Provedores } \\
\hline $\begin{array}{l}\text { Nicolau dos Reis Fonseca Borges - para o Districto da vila da Praia na Ilha de S. } \\
\text { Thiago, Ex- Capitão -Mór, e Morgado }\end{array}$ \\
\hline $\begin{array}{l}\text { Luiz Freire de Andrade - Coronel de Milicias, para o Districto de S.ta Catharina, } \\
\text { na mesma Ilha de S. Thiago; Morgado }\end{array}$
\end{tabular}

27 AHN, $S G G$, "Ofícios expedidos ao Ministério e Secretaria de Estado da Marinha e Ultramar" (1830/Abr/02 - 1836/Jan/13). Cópias manuscritas, liv. 520, de 16 de Maio de 1834. 


\begin{tabular}{|l|}
\hline Antonio Carlos d'Araujo - Rico proprietário, para o Districto da Ilha Brava \\
\hline $\begin{array}{l}\text { Antonio Carlos de Mello - Tenente Coronel de Milicias, rico negociante, para o } \\
\text { Districto da Ilha do Maio }\end{array}$ \\
\hline Francisco Joze de Senna - Rico proprietário, para o Districto da Ilha Brava \\
\hline $\begin{array}{l}\text { João Antonio Leite - Major de Milicias; da opulenta familia Dias, para o Districto } \\
\text { da Ilha de S. Nicoláu }\end{array}$ \\
$\begin{array}{l}\text { Luis Antonio de Mello - Rico proprietário, para o Districto das Ilhas de Sto. Antão, } \\
\text { e S. Vicente }\end{array}$ \\
\hline $\begin{array}{l}\text { Joaquim Pereira da Silva - Major de Milicias com soldo, rico proprietário, } \\
\text { da Liberdade }\end{array}$ \\
\hline
\end{tabular}

A nova organização administrativa proposta pelo prefeito de Cabo Verde baseava-se na criação de modelos de provedores e sub-prefeitos nos distritos que, na prática, manteriam os mesmos poderes das câmaras municipais. Note-se que os dois provedores propostos para a ilha de Santiago eram os morgados mais abastados da ilha de Santiago. Apesar das reformas administrativas impressas na máquina burocrática de Cabo Verde, no interior da ilha de Santiago o poder político continuou a ser monopolizado pelos morgados. Além de destacar o nome dos novos provedores, o prefeito também destacou as "faculdades" político-econômicas dos mesmos: "morgado" ou "rico proprietário". As nomeações demonstram que para poder exercer um cargo político, tornava-se necessário que o indivíduo tivesse bens ou propriedades. Tais reformas foram duramente contestadas pelos segmentos políticos, principalmente do interior da ilha de Santiago. Para os rendeiros, tais reformas não iam ao encontro das suas aspirações por uma maior participação política. Por meio desta nova organização administrativa, a prefeitura pretendia “(...) a extinção dos ódios e discórdias civis, e de conciliarem, e reunirem em hum só espírito, e obediência todos os membros da Família Portugueza, para que fazem mais pertinares e ousados os maos Cidadãos inimigos da ordem publica (...)". ${ }^{28}$ Porém, os liberais exaltados não acreditavam nas reformas, tendo em vista que os cargos políticos continuaram sendo

28 AHN, $S G G$, Portarias do Ministério do Reino (Janeiro - Dezembro/1834). Originais manuscritos, Cx. 285. 
ocupados por ricos morgados e comerciantes da ilha de Santiago. A leitura desse ofício possibilitou a esta pesquisa articular os "ódios", as "discórdias civis" e políticas na emergência de ações contestatórias no interior da ilha de Santiago. Os exaltados eram designados como sendo "inimigos da ordem pública", uma vez que promoviam ações contestatórias contra o governo dos moderados.

Entretanto, todas essas reivindicações seriam, em parte, atendidas pelos ofícios de 21 de junho de 1834 e de 12 de julho de 1834, que colocaram em prática as determinações do Decreto, de 28 de maio desse mesmo ano, que determinou a eleição de deputados às Cortes em Cabo Verde, garantindo assim os direitos políticos àqueles que podessem exercer o direito ao voto. Já o ofício de 12 de Julho determinou a realização das eleições paroquiais, compelindo os eleitores das ilhas de: Santiago, Maio, Fogo e Brava a se reunirem no dia 15 de agosto na ilha da Boa Vista para elegerem os deputados às Cortes, tendo em vista que as moléstias e doenças provocadas pelo período de chuvas impediriam sua realização na ilha de Santiago. Além disso, para uma maior eficácia no cumprimento das portarias remetidas de Lisboa, o conselheiro advertiu quanto à necessidade de aplicação das determinações régias, de acordo com as circunstâncias peculiares de cada freguesia, de cada concelho e de cada paróquia.

(...) Parte das Instruções de 7 de Agosto de 1826, que se refere ás Elleições Parochiaes ás quaes VS ${ }^{\mathrm{a}}$. se servirá mandar proceder sem demora nas Ilhas de Santiago, Maio, Fogo e Brava, que se achão debaixo da sua immediata direcção; remettendo para isso às respectivas Camaras Copias das dittas Instrucções; e fazendo-lhes saber que os Elleitores se devem reunir impreterivelmente no dia 15 d'Agosto do corrente anno para formarem a Assemblea Provincial, na Ilha da Boa Vista, actual residencia da Prefeitura; pois seria tão improprio, como inhumano sugeitar os Cidadãos Elleitores das outras Ilhas ás molestias agudas, e perigozas, que nesta Quadra são quasi inevitaveis na Ilha de $\mathrm{S}$. Thiago, aonde aliás se acha dissolvida por falta de população a Camara da arruinada, e deserta Cidade da Ribeira Grande, que servia de Capital (...). ${ }^{29}$

O ofício acima referido destaca as motivações de ordem naturais e econômicas que intervieram na escolha da ilha da Boa Vista para a realização das eleições para deputados às Cortes em Portugal. Também não deixou de destacar a ausência da população na Ribeira Grande, onde habitualmente eram realizadas as eleições. Além dos fatores anunciados pelo

29 AHN, SGG, Cx. 119. 
ofício, era do interesse político da prefeitura realizar as eleições na ilha da Boa Vista, tendo em vista a decisiva influência nos resultados do escrutínio. Com esta iniciativa política, a prefeitura pretendia minimizar as manipulações dos resultados por parte das elites locais da ilha de Santiago, como também favorecendo os eleitores das ilhas do barlavento, como São Vicente, Santo Antão, São Nicolau e Boa Vista. Por isso, a prefeitura tinha todo o interesse que as eleições fossem realizadas na ilha da Boa Vista, donde partiram as mobilizações políticas em torno dos princípios liberais em Cabo Verde. É importante reiterar que para o liberalismo, o indivíduo é o principal destinatário do poder político, tornado pelo contrato social um cidadão.

Segundo o relatório de 26 de agosto de 1834, o então prefeito de Cabo Verde, Manoel Antonio Martins, comunicou à Coroa portuguesa que as eleições nas várias ilhas de Cabo Verde decorreram com a maior "liberdade e ordem", apesar de falta de pessoas ilegíveis segundo a legislação vigente. Também não deixou de destacar as grandes distâncias percorridas pelos eleitores e a necessidade de adaptar as diversas determinações régias às circunstâncias locais, como principais dificuldades para o processo eleitoral no interior da ilha de Santiago. Foram eleitos Joaquim da Silva e o secretário geral da prefeitura, Joze Joaquim Lopes de Lima, apoiantes desde 1824 do governo constitucional. Para tanto, destacou a importância da organização tanto dos "Registros Civis" quanto das "pautas juramentadas" nos diversos concelhos.

No que se refere à prefeitura, esta determinou, sob pretexto de manter a tranquilidade pública e a monarquia constitucional, a criação de uma Guarda Nacional, formada por cidadãos tidos como idôneos. A estratégia dos morgados visava constituir uma milícia em cada freguesia pretendendo, com isso, impedir que os rendeiros organizassem revoltas contra os seus morgados. Caberia às autoridades locais das freguesias a escolha desses cidadãos tidos como "qualificados" para ocuparem o posto de guarda nacional. Como exigência os candidatos deveriam ter 100 mil reis de renda anual, proveniente tanto dos bens de raiz, do comércio e da indústria, o que excluía os rendeiros. Também estavam fora desta qualificação os condenados por roubo, atentado aos costumes e a moral pública. Os provedores de justiça dos concelhos deveriam observar as exigências impostas pelo Decreto. Caberia as autoridades locais solicitar a intervenção da guarda nacional, em caso de desordem que colocasse em causa a tranquilidade pública das pessoas e bens.

Com a deposição do prefeito, Manoel Antonio Martins, acusado de atacar os liberais 
exaltados da ilha, se pretendendo atender às reivindicações políticas dos liberais moderados, tornava-se urgente a realização de novas eleições nas diversas freguesias do interior da ilha de Santiago. Pelos ofícios dirigidos ao prefeito de Cabo Verde, Manoel Antonio Martins, dos dias 5, 12 e 21 de julho de 1834, o conselheiro honorário da prefeitura e encarregado da administração das ilhas de Cabo Verde, Joaquim Joze Pereira demonstrou a urgência quanto às eleições de deputados às Cortes, segundo o Decreto de 28 de maio daquele ano. Segundo este ofício, tornava-se indispensável a realização de eleições paroquiais para cargos políticos locais nas ilhas de Santiago, Maio, Boa Vista, Fogo e Brava, por forma a conseguir que todos os eleitores da provìncia pudessem reunir no dia 15 de agosto, evitando protestos de desordens nas referidas ilhas. Além disso, apesar das grandes distâncias que separavam as freguesias umas das outras, reiterou que a prefeitura vinha se esforçando para enviar a todas as câmaras da província as cópias das determinações das Cortes, de 26 de Agosto de 1826, para que as eleições fossem realizadas o mais breve possível.

Sob pressão dos exaltados foram eleitos novos eleitores para representarem o concelho de Santa Catarina. Segundo o ofício de 8 de agosto de 1834, o referido conselheiro apresentou Paulo Jozé dos Mosquitos de Santa Maria e João Pereira de Barros como sendo os novos eleitores desse concelho. Além disso, sugeriu aos vigários de todas as freguesias do interior da ilha de Santiago que, devido tanto às grandes distâncias percorridas pelos candidatos diante da extensão das freguesias e pela pobreza dos seus habitantes, que a eleição fosse realizada numa localidade, num ponto central, no interior da ilha. Esta fala oficial demonstra que os rendeiros do interior da ilha de Santiago reivindicavam uma representação política junto ao governo geral. Para tal, exigiram que o prefeito procedesse à eleição dos deputados também no interior da ilha de Santiago como determinava a Carta constitucional de 1826, posteriormente substituída pelas Cartas de 1822 e de $1838 .{ }^{30}$ Esses políticos exigiam não só novas eleições, como também novas condições para a realização delas. Damos destaque a aquela que determinava que fosse fixado um local mais próximo para o ato eleitoral.

Entretanto, a simples realização de novas eleições para cargos dentro dos concelhos não agradou as elites políticas que, por sua vez, exigiram profundas reformas quanto à

30 AHN, $S G G$, Correspondências trocadas entre o prefeito de Cabo Verde, Manoel Antonio Martins, e os secretários e o conselheiro honorário da prefeitura (Abril - Dezembro/1834). Originais e cópias manuscritos. Cx. 119. 
distribuição das riquezas. Para tal, o governo geral deveria mudar os "usos e costumes", por meio de fundação de "pequenas povoações" que favorecessem tanto o comércio interno quanto o comércio externo de Cabo Verde. Para o aumento das riquezas do arquipélago e do seu "povo", a Coroa deveria apostar na fundação de um novo "centro de civilização" que, segundo o governador geral Joaquim Marinho, deveria ser sediado na ilha de São Vicente. Nesta ilha poderia ser estabelecido um depósito de todas as produções agrícolas, manufatureiras das restantes ilhas de Cabo Verde e da costa da Guiné, o que facilitaria o comércio e "sem risco algum para todos os europeos". Tal iniciativa reanimaria o comércio e a navegação com os portos da ingleses e franceses. Segundo o mesmo governador, a Coroa portuguesa deveria "fazer hum centro de cevilização, para dali se espalhar as outras ilhas, onde se devem assentar todos os estabelecimentos da industria, de comercio e da navegação".

Por outro lado, deveria também criar novas leis que aumentando as rendas do governo permitissem acabar com o deficit. O governo geral utilizava o argumento legal que o trabalho enaltecia os valores da civilização, enquanto que a indolência estava associada à selvageria. Além disso, a ilha dispunha de bons portos, sendo sua posição geográfica " $a$ mais vantajoza pela navegação" para os navios que iam para o sul, e era capaz de receber "mais de duzentos grandes navios, e muitas especies de embarcações pequenas". Esta estratégia política visava não só impedir que os rendeiros tivessem acesso aos cargos políticos, como também educar a população nos valores da "civilização européia"." Segundo o prefeito Manoel Antonio Martins, os rendimentos públicos em Cabo Verde provinientes dos impostos não chegavam sequer a uma quinta parte do que seriam necessários para pagar os funcionários e suportar as despesas públicas, pressupostos fundamentais em qualquer país civilizado.

Segundo o relatório de 26 de agosto de 1834, o então prefeito de Cabo Verde, Manoel Antonio Martins, comunicou à Coroa portuguesa que as eleições nas várias ilhas de Cabo Verde decorreram com a maior "liberdade e ordem", apesar de falta de pessoas ilegíveis segundo a legislação vigente. Também não deixou de destacar as grandes distâncias percorridas pelos eleitores e a necessidade de adaptar as diversas determinações régias às circunstâncias locais, como principais dificuldades para o processo eleitoral no interior da ilha de Santiago. Foram eleitos Joaquim da Silva e o secretário geral da 31 AHU, SEMU: Oficios do governador Joaquim Pereira Marinho. Cx. 53, doc. 31. 
prefeitura, Joze Joaquim Lopes de Lima, apoiantes desde 1824 do governo constitucional. Para tanto, destacou a importância da organização tanto dos "Registros Civis" quanto das "pautas juramentadas" nos diversos concelhos.

No que se refere à prefeitura, esta determinou, sob pretexto de manter a tranquilidade pública e a monarquia constitucional, a criação de uma Guarda Nacional, formada por cidadãos tidos como idôneos. A estratégia dos morgados, detentores de cargos administrativos, visava constituir uma milícia em cada freguesia pretendendo, com isso, impedir que os rendeiros organizassem revoltas contra os seus morgados. Caberia às autoridades locais das freguesias a escolha desses cidadãos tidos como "qualificados" para ocuparem o posto de guarda nacional. Como exigência os candidatos deveriam ter 100 mil reis de renda anual, proveniente tanto dos bens de raiz, do comércio e da indústria, o que excluía os rendeiros. Também estavam fora desta qualificação os condenados por roubo, atentado aos costumes e a moral pública. Os provedores de justiça dos concelhos deveriam observar as exigências impostas pelo Decreto. Caberia as autoridades locais solicitar a intervenção da guarda nacional, em caso de desordem que colocasse em causa a tranquilidade pública das pessoas e bens.

Para coibir tais práticas arbitrárias e abusivas, a provedoria do concelho de Santa Catarina determinou, em consonância com as deliberações tomadas pela Câmara Municipal de Santa Catarina, que em todas as compras e vendas se observassem as medidas e padrões estabelecidos pela provedoria, de acordo com o Alvará de 15 de julho de 1779. Caso contrário, incorreria em multa de cinco mil reis pela primeira prática e, sendo reincidente, receberia uma multa de 10 mil reis, além de pena de prisão de um mês, revertendo metade da multa para o concelho e outra metade para o denunciante. Ainda solicitava a colaboração de todos os habitantes do concelho quanto ao cumprimento dos pesos e medidas estabelecidas pela provedoria, uma vez que os abusos praticados pelos morgados resultavam em grande prejuizo para a agricultura no interior da ilha de Santiago. É importante salientar que durante o governo de D. António Coutinho de Lencastre (1804 1811), foram enviados de Lisboa instrumentos de pesos e medidas. Porém, na prática, os morgados não executavam as determinações do governo geral, o que inviabilizou a pretensão do governo de padronizar pesos e medidas nas vendas e compras. Os provedores de justiça, instituído pela prefeitura, se apresentavam como defensores dos mais fracos, dentre os quais, os pobres rendeiros do interior da ilha de Santiago. 
Segundo a portaria de 6 de novembro de 1834, remetida pelo prefeito de Cabo Verde, os morgados do interior da ilha de Santiago, entre os meses de janeiro e fevereiro, deveriam comprar todas as colheitas dos seus rendeiros pelo preço de 300 a 400 reis um alqueire, deveriam revendendê-las nos meses de setembro e outubro pelo preço de 1000 a 1200 reis. Caso o rendeiro recusasse a vender por um preço baixo as suas colheitas ao morgado poderia até ser expulso injustamente das terras onde constituiu a sua família. Esta tática econômica estava articulada a uma estratégia política que visava empobrecer cada vez mais o rendeiro que já vivia em extrema pobreza. Apesar das determinações da Coroa portuguesa para favorecer o comércio público e a economia, os morgados do interior da ilha de Santiago continuavam tendo práticas de tirannia e monopólio das riquezas geradas pela terra. O mesmo prefeito considerou que os "criminosos abuzos de monopolios, revenda e travessias" de gêneros estavam proibidas pela Ordenação, Liv. 5, folhas 76, como também previstas nos Alvarás de 4 de outubro de 1644, de 24 de setembro de 1649, de 20 de outubro de 1651, quanto pelos Decretos de 25 de janeiro de 1679 e de 12 de agosto de 1695. Por isso, determinou que os provedores, nos limites da suas jurisdições, fiscalizassem o "criminoso monopolio do milho ou qualquer outro mantimento de primeira necessidade", previnindo e policiando todas as práticas comerciais, garantindo a concorrência. Além disso, os provedores deveriam divulgar regulamentos que favorecessem a "economia pública", impondo grandes penalidades para os infratores, por meio de constituição de processos crimes. Esta fala oficial revela a estratégia política dos morgados que, por meio da transgressão da legislação vigente, compravam todas as colheitas dos seus rendeiros e faziam o monopólio do livre comércio de bens no interior da ilha de Santiago. O prefeito mantinha sua oposição política aos morgados defensores de governos militares, denunciando suas iniciativas econômicas contra os seus respectivos rendeiros.

\section{REFERÊNCIAS BIBLIOGRÁFICAS}

CAETANO, Marcello José das Neves Alves. História do direito português (Fontes direito público: 1140 - 1495). 3 a . ed., Lisboa: Ed. Verbo, 1992.

CARREIRA, António. Cabo Verde: Formação e Extinção de uma sociedade escravocrata (1460 - 1878). Porto: Imprensa portuguesa, 1972.

DOMINGUES, Ângela. "Administração e Instituições: Transplante, Adaptação, Funcionamento". In: História Geral de Cabo Verde. Coordenação de Luís de Albuquerque e Maria Emília Madeira Santos. Lisboa: Centro de Estudos de História e 
Cartografia Antiga e Instituto de Investigação Científica Tropical; Praia: Direcção Geral do Patrimônio Cultural de Cabo Verde, 1991, v. I.

FURTADO, Cláudio Alves. Transformação das Estruturas Agrárias numa Sociedade em mudança - Santiago Cabo Verde. São Paulo, 1988. 357 f. Dissertação (Mestrado em Sociologia) - Faculdade de Filosofia, Letras e Ciências Humanas, Universidade de São Paulo.

HESPANHA, António Manuel. História das Instituições: época medieval e moderna. Coimbra: Livraria Almedina, 1982.

\section{Documentos pesquisados}

\section{Manuscritos}

Arquivo Histórico de Cabo Verde (A.H.N.) - Secretaria Geral do Governo (S.G.G.).

Caixas: 119; 285.

Livro: 520.

Arquivo Histórico Ultramarino (A.H.U.) - Cabo Verde - Concelho Ultramarino (C.U.).

Caixas: 49, 53, 60, 77.

Arquivo Arquivo Romano da Companhia de Jesus (ARSI), Roma

Cod.: $\mathrm{n}^{\circ} 74$.

Arquivo Nacional da Torre do Tombo (ANTT)

Chancelaria de D. Manuel, Livro 30.

Chancelaria de D. João III, Livro 21.

Carta dos moradores da ilha de Santiago - ANTT, Gavetas, 3-10-8. Ribeira Grande, Maio de 1510.

Maço 8, Livro da receita da renda de Cabo Verde - anos de 1513 - 1516.

Livro das Ilhas, fl. $69 \mathrm{v}$.

\section{Periódicos} 1845.

Boletim Oficial do Governo Geral de Cabo-Verde, Nº 119, de 27 de Dezembro de

\section{Legislação}

Ordenações Afonsinas (reprodução fac-similada da edição da Universidade de Coimbra de 1792), 5 v., Fundação Calouste Gulbenkian, Lisboa, 1984, Liv. I. 